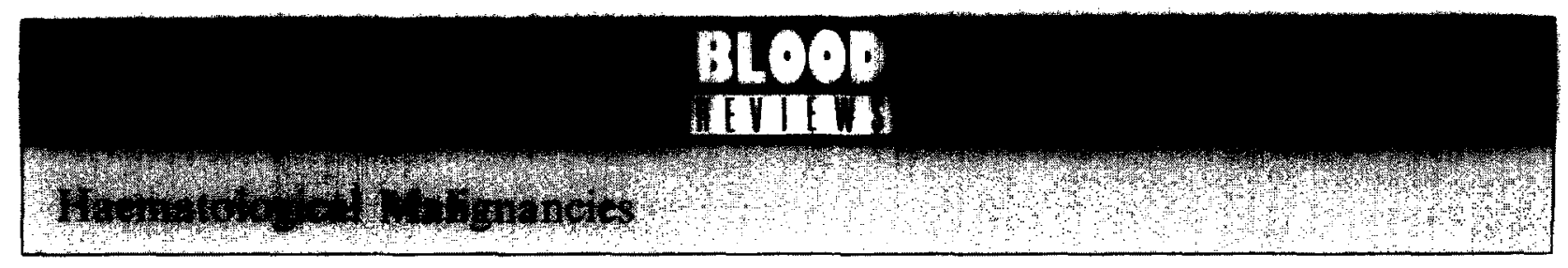

\title{
Immunologic Classification of Lymphoma and Lymphoid Leukemia
}

\author{
K. A. Foon, R. P. Gale
}

SUMMARY. Important insights into lymphocyte differentiation and the cellular origins of lymphoma and lymphoid leukemia have been gained through the use of monoclonal antibodies that define cell surface antigens and molecular probes that identify immunoglobulin and $T$ cell receptor genes. Results of these studies have been combined with markers such as surface membrane and cytoplasmic immunoglobulin on B lymphocytes, sheep erythrocyte receptors on $T$ lymphocytes, and cytochemical stains. Utilising all of the above markers, it is now clear that acute lymphoblastic leukemia (ALL) is heterogeneous. Furthermore, monoclonal antibodies that identify $B$ cells such as the anti-B1 and anti-B4 antibodies in combination with studies of immunoglobulin gene rearrangement have demonstrated that virtually all cases of non-T-ALL involve B lymphocytes. At least six distinct subgroups of non-T-ALL can now be identified. T-ALL is subdivided by the anti-Leu-9, anti-Leu-1, and additional antibodies that separate $T$ lymphocyte subsets into three primary subgroups. Monoclonal antibodies are also useful in the subclassification of non-Hodgkin's lymphoma, and certain distinct markers can be correlated with morphologic classification.

Recent advances in immunology have led to important insights into lymphocyte differentiation and the cellular origin of lymphoma and lymphoid leukemia. It is now possible to precisely define stages of human lymphocyte differentiation utilising highly specific monoclonal antibodies that define cell surface antigens and molecular probes that identify rearrangement of immunoglobulin and $T$ cell receptor genes. These can be combined with more traditional cell markers such as surface membrane (SmIg) and cytoplasmic immunoglobulin $(\mathrm{CIg})$ on $\mathrm{B}$ lymphocytes, sheep erythrocyte receptors on $\mathrm{T}$ lymphocytes, and cytochemical stains. In this review, we summarise advances in the classification of lymphoma and the lymphoid leukemias and their importance in our understanding normal lymphoid differentiation and therapeutic implications.

K. A. Foon, Division of HematolOgy and Oncology, Department of Internal Medicine, University of Michigan, Ann Arbor, MI and R P Gale, the Division of Hematology and Oncology, Department of Internal Medicine, and the Transplantation Biology Unit, University of California, Los Angeles.

\section{Cell Markers}

\section{B Lymphocytes}

B lymphocytes are usually identified by the presence of SmIg. Progenitors of B lymphocytes, commonly referred to as 'pre-B cells' are present in fetal liver and normal bone marrow; the cells display cytoplasmic $\mu$-heavy chain $(\mathrm{C} \mu)$ but lack intracytoplasmic light chain and SmIg. B and pre-B lymphocytes may also have receptors for the third component of complement $\left(C^{\prime} 3\right)$ and for the $\mathrm{Fc}$ portion of $\mathrm{IgG}$. Fc and $C^{\prime} 3$ receptors are not specific for the $B$ cell lineage and are found in other cells such as monocytes and some nonhematopoietic cells. Similarly, histocompatibility-related antigens (Ia or HLA-DR) are also found on the surface of B cells, but are not unique to them. ${ }^{1-4}$ Plasma cells are the most mature $B$ lymphocytes; they lack detectable SmIg but have CIg. Unlike the CIg found in pre-B lymphocytes, $\mathrm{CIg}$ in plasma cells includes both heavy and light chains.

A number of heteroantisera and, more recently, monoclonal antibodies that identify B cell-associated 
Table 1 Monoclonal Antibodies Reactive with Human B Lymphocytes

\begin{tabular}{|c|c|c|c|c|}
\hline Antibody (subclass) & Pattern of Reactivity & $\begin{array}{l}\text { Molecular Weight } \\
\text { of Antigen (kd) }\end{array}$ & $\begin{array}{l}\text { Cluster } \\
\text { Designation }\end{array}$ & Reference \\
\hline anti-B1 & B lymphocytes, malignant B cells & 35 & $\mathrm{CD} 20$ & 8 \\
\hline \multirow[t]{2}{*}{ anti-B2 } & B lymphocytes, malignant B cells (receptor for & & & \\
\hline & Epstein-Barr virus and $C 3 d$ ) & 140 & CD21 & 9,10 \\
\hline anti-B4 & B lymphocytes, malignant B cells & 40 & CD19 & 7 \\
\hline BA-1 & B lymphocytes, granulocytes, malignant B cells & $45,55,65$ & $\mathrm{CD} 24$ & 11,12 \\
\hline FMCl & B lymphocytes, malignant B cells & NR & NA & 13 \\
\hline \multirow{3}{*}{$\begin{array}{l}\text { FMC7 } \\
\text { J5, BA-3 }\end{array}$} & $<50 \%$ B lymphocytes, some malignant B cells & NR & NA & 14 \\
\hline & $\begin{array}{l}\text { Granulocytes, most non-T-ALL, Burkitt's } \\
\text { lymphoma, follicular lymphoma, some }\end{array}$ & & & \\
\hline & lymphoblastic lymphoma and T-ALL & 100 & $\mathrm{CDl0}$ & $4-6$ \\
\hline $\begin{array}{l}\text { anti-PCA-1 and anti- } \\
\text { PCA } 2\end{array}$ & $\begin{array}{l}\text { Plasma cells, malignant plasma cells, weakly on } \\
\text { monocytes and granulocytes }\end{array}$ & NR & NA & 15 \\
\hline anti-PC-1 & Plasma cells, malignant plasma cells & 28 & NA & 16 \\
\hline
\end{tabular}

NR, not reported; NA, not applicable.

The anti-B series, anti PC-1, and anti PCA-1 are available through Coulter Immunology, Hialeah, Florida; BA-1 through Hybritech Inc., San Diego, California; and the OKB series through Ortho System, Inc., Raritan, NJ.

Table 2 Monoclonal Antibodies Reactive with Human T Lymphocytes

\begin{tabular}{|c|c|c|c|c|}
\hline Antibody & Pattern of Reactivity & $\begin{array}{l}\text { Molecular Weight } \\
\text { of Antigen (kd) }\end{array}$ & $\begin{array}{l}\text { Cluster } \\
\text { Designation }\end{array}$ & Reference \\
\hline OKT6, NA1/34, anti-Leu-6 & Thymocytes & 45 & CD1 & 21 \\
\hline OKT11, anti-T11, anti-Leu-5 & Pan-T lymphocyte (E receptor) & $40-50$ & $\mathrm{CD} 2$ & 23,24 \\
\hline OKT3, anti-T3, anti-Leu-4 & Pan-T lymphocyte (mitogenic) & $20,20,25$ & $\mathrm{CD} 3$ & 21 \\
\hline OKT4, anti-T4, anti-Leu-3 & T helper/inducer & 55 & CD4 & 21,22 \\
\hline OKT1, anti-T1, anti-Leu- 1 , T101 & Pan-T lymphocyte, pan-thymocyte & 65 & CD5 & $21,25,26$ \\
\hline $3 \mathrm{Al}$, anti-Leu-9 (4H9), WT1 & Pan-T lymphocyte, pan-thymocyte & 40 & CD7 & $27-29$ \\
\hline OKT5, OKT8, anti-T8, anti-Leu- 2 & T cytotoxic/suppressor & $32-43$ & CD8 & 22 \\
\hline Anti-Tac & Interleukin-2 receptor & 55 & CD25 & 31 \\
\hline Anti-TQ1 & Subset of $T$ inducer cells & NR & NA & 31 \\
\hline OKT9, 5E9 & $\begin{array}{l}\text { Thymocytes, lymphoblasts, monocytes } \\
\text { (anti-transferrin) }\end{array}$ & 90 & NA & 20,21 \\
\hline OKT10 & Thymocytes & 45 & NA & 20 \\
\hline
\end{tabular}

NR. not reported; NA, not applicable.

The OKT series of antibodies are available through Ortho Systems, Inc., Raritan, NJ; Leu series through Becton-Dickinson Co., Mountainview, California; anti-T through Coulter Immunology, Hialeah, Florida; and T101 through Hybritech, Inc., San Diego, California.

antigens have been described (Table 1).4-16 For a more detailed description of these antibodies see reference 17. Where applicable, the nomenclature and clusters of differentiation (CD) defined by the Second International Workshop on Human Leukocyte Differentiation Antigens are shown. ${ }^{18,19}$

\section{TLymphocytes}

$\mathrm{T}$ lymphocytes were initially identified by their ability to spontaneously bind sheep erythrocytes ( $\mathrm{E}$ rosette). $T$ lymphocytes also react with $T$ cell-specific antisera and $T$ cell monoclonal antibodies which may also be used to identify $T$ lymphocytes, and have proven to be more sensitive and discriminatory (Table 2). ${ }^{20-31}$ Many of these antibodies react with immature T cells; others react with more mature $T$ cells. Some of these antibodies identify antigens found on all $\mathrm{T}$ cells, whereas others occur only on $T$ cell subsets.

A summary of the more frequently referenced antibodies useful for the classification of lymphoma and lymphoid leukemia, and their cluster designations is shown in Table 3.
Table 3 Frequently Referenced Antibodies with Cluster Designations

\begin{tabular}{ll}
\hline Cluster Designation & Antibody \\
CD1 & OKT6, anti-Leu-6, NA1/34 \\
CD2 & OKT11, anti-T11, anti-Leu-5, 9.6 \\
CD3 & OKT3, anti-T3, anti-Leu-4, UCHT-1 \\
CD4 & OKT4, anti-T4, anti-Leu-3 \\
CD5 & OKT1, anti-T1, anti-Leu-1, 10.2, T101 \\
CD7 & anti-Leu-9, 3A1, WT1, 4A \\
CD8 & OKT5, OKT8, anti-T8, anti-Leu-2 \\
CD10 & anti-J5, BA-3, anti-CALLA \\
CD19 & anti-B4 \\
CD20 & anti-B1 \\
CD21 & anti-B2 \\
CD24 & BA-1 \\
CD25 & anti-Tac \\
\hline
\end{tabular}

\section{Immunoglobulin and T Cell Receptor Genes}

Recombinant DNA technology has provided important insights into antibody diversity and antigenspecific $\mathrm{T}$ cell receptors. ${ }^{32}$ Immunoglobulins are composed of heavy and kappa and lambda light chains, encoded by genes on chromosome 14,2 or 22 , respectively. ${ }^{33-36}$ Immunoglobulin genes are encoded bv 
discontinuous segments of DNA.$^{37,38}$ At one point in development, a potential antibody-producing cell must productively rearrange variable, diversity and joining genes (VDJ) which are then linked to the constant region locus. Immunoglobulin gene rearrangements are hierarchal; $\mu$ heavy chain rearrangements precede light chain rearrangements; kappa light chain rearrangement precedes lambda light chains rearrangement. ${ }^{38}$ These rearrangements can be detected by Southern blot analyses of DNA from B-cells using appropriately radiolabeled heavy or light chain probes. Heavy chain rearrangements have been identified in non-B cells; light chain rearrangements appear to be restricted to B-cells. ${ }^{38,39}$ Clonal rearrangements of light chain genes are therefore an extremely sensitive tool to identify B-cell malignancies.

The antigen-specific T-cell receptor is a heterodimer formed by a $40-50$ kilodalton (kd) $\alpha$ subunit (T $\alpha$ ), and a $40-45 \mathrm{kd} \beta$ subunit $(\mathrm{T} \beta) .{ }^{40}$ It is associated with three $20-25 \mathrm{kd}$ peptide chains identified by the T3 monoclonal antibody. ${ }^{40}$ Recently, cDNA clones to the $\mathrm{T} \beta$ and T $\alpha$ receptors have been isolated..$^{41-43}$ The human $\mathrm{T} \beta$ receptor gene has been localised to chromosome $7^{44}$ and the human $\mathrm{T} \alpha$ receptor gene to chromosome $14 .^{45}$

$\mathrm{T} \beta$ gene rearrangements have been detected in malignant human $\mathrm{T}$-cells by Southern blotting. ${ }^{46} 48$ This technique can detect as few as $1 \%$ tumour cells in a mixed cell population; ${ }^{46}$ it is a sensitive diagnostic marker for $\mathrm{T}$-cell diseases. Interestingly, rearrangements of the T $\beta$ antigen receptor are reported in $25 \%$ of patients with non-T ALL, ${ }^{49}$ and in a small portion of leukemic B cells. ${ }^{50}$ This is similar to the rearrangement of immunoglobulin heavy chain genes in approximately $10 \%$ of the leukemic $\mathrm{T}$ cell population studied. ${ }^{39}$

\section{Classification of the Lymphoid Leukemias and Lymphomas}

\section{Acute Lymphoblastic Leukemia}

Acute lymphoblastic leukemia (ALL) is heterogeneous. The first surface markers used to differentiate subclasses of ALL were $E$ rosettes, ${ }^{51,52}$ which identify a T cell subclass (15-20\% of cases) and SmIg which identifies a $B$ cell subset ( $<5 \%$ of cases). Both $T$ and $B$ cell subgroups have an unfavourable prognosis. ${ }^{53,54}$ The next important advance in identifying ALL was development of an antiserum to the common ALL antigen (CALLA). ${ }^{55}$ CALLA or CD10 reactivity identified a non- $B$, non-T subclass of ALL patients (approximately $70 \%$ of cases) with a more favourable prognosis than T-ALL, B-ALL, or non-B, non-T ALL without CD10. ${ }^{54}$ Other markers such as Ia antigen were commonly found on non- $\mathrm{T}$ ALL and could help differentiate non- $T$ from $T$ ALL. ${ }^{56}$ By testing for cytoplasmic $\mu$ heavy chain, a subset designated pre-B ALL has been identified. ${ }^{57}$ Except for the presence of cytoplasmic $\mu$, this subset expresses the same surface markers as the CD10- positive form of non-T-ALL; it appears, however, to have a less favourable prognosis. ${ }^{58}$

With the development of monoclonal antibodies, it became evident that the T cell subset of ALL was heterogeneous. ${ }^{59-61}$ More recently, studies of immunoglobulin gene rearrangements and monoclonal antibodies that identify $B$ cell-associated antigens have demonstrated that most cases of non-T-ALL derive from the $B$ cell lineage. ${ }^{62.63}$ We review these data and present a new classification for ALL based on these recent observations.

\section{Non-T-Acute Lymphoblastic Leukemia}

Two important areas of research have prompted a reassessment of non-T-acute lymphoblastic leukemia (non-T-ALL). First, monoclonal antibodies that recognise $B$ cell-associated antigens have been identified; many are present on non-T-ALL cells. The most specific of these antibodies is probably anti-B4 which reacts with $95 \%$ of cases of non-T-ALL. ${ }^{11,63}$ Second, clonal rearrangements of immunoglobulin genes provide strong evidence for the $\mathrm{B}$ cell lineage of most cases of non-T-ALL. ${ }^{62,63}$

Although Ia antigen is present on most non-TALL, and CD10 is present on $75 \%$ of cases of non-T-ALL, these antigens are also identified on approximately $10 \%$ of cases of T-ALL. Therefore, B cell-associated antigens (Table 1), which are not identified on T-ALL cells, are the most useful in distinguishing non-T-ALL. The CD20 and CD19 antigens are model antigens for this discussion.

Less than $5 \%$ of cases of ALL express SmIg (usually $\operatorname{IgM}$ ); these cells are typically classified as B-ALL. These cells generally express other B cell antigens, including CD20, CD19, and Ia. B-ALL in children is probably a leukemic phase of non-Hodgkin's or Burkitt's lymphoma. ${ }^{52,53}$ Another marker that identifies a subset of non-T-ALL is cytoplasmic $\mu(\mathrm{C} \mu)$ heavy chain; $\kappa$ and $\lambda$ light chains, and SmIg, are typically absent. ${ }^{57}$ These cells are considered pre-B cells. As indicated, most cases of non-TALL involve pre-B cells; thus $\mathrm{C} \mu$ is useful in determining the level of differentiation of pre-B cells. Pre-B cells that synthesise $\mu$ heavy chain are the most mature cells of this group.

Nadler and co-workers ${ }^{63}$ recently classified 138 patients with non-T-ALL on the basis of monoclonal antibodies and immunoglobulin gene rearrangements. They divided these cases into four major subgroups. The first subgroup was Ia antigen-positive, representing $5 \%$ of cases. Another subgroup expressed the Ia and $\mathrm{B} 4$ antigens representing $15 \%$ of cases. The third subgroup expressed the Ia, CD19, and CD10 antigens, comprising one third of the cases. Finally, one half of the cases of non-T-ALL were Ia, CD19, CD10, and CD20 positive. The fourth group was further subdivided into cases with and without $\mathrm{C} \mu$. We propose that cases with $\mathrm{C} \mu$ be placed in a separate group (group $\mathrm{V}$ ) assuming that they are more mature. 
Table 4 Classification of non-T-ALL

\begin{tabular}{|c|c|c|c|c|c|c|}
\hline & \multicolumn{4}{|c|}{ Antigens } & \multirow[b]{2}{*}{ Cytoplasmic $\mu$} & \multirow{2}{*}{$\begin{array}{l}\text { Surface Membran } \\
\text { Immunoglobulin }\end{array}$} \\
\hline & Ia & CD19 & CD10 & $\mathrm{CD} 20$ & & \\
\hline Group I & + & - & - & - & _- & - \\
\hline Group II & + & + & - & - & - & - \\
\hline Group III & + & + & + & - & - & - \\
\hline Group IV & + & + & + & + & - & - \\
\hline Group V & + & + & + & + & + & - \\
\hline Group VI & + & + & $+1-$ & + & - & + \\
\hline
\end{tabular}

Table 5 Classification of T-ALL

\begin{tabular}{llllllll}
\hline & \multicolumn{7}{c}{ Antigens } \\
\cline { 2 - 7 } & CD7 & CD5 & CD2 & CD3 & CD4 & CD8 & CD1 \\
\hline Group I & + & $+(90 \%)$ & $+(75 \%)$ & - & - & - & - \\
Group II & + & + & + & $+(25 \%)$ & $+(90 \%)$ & $+(90 \%)$ & + \\
Group III & + & + & + & + & $+/-\dagger$ & $+1-\dagger$ & - \\
\hline
\end{tabular}

* Found on virtually all T-ALL cells.

$\dagger$ No longer simultaneous expression of T4/Leu-3 and T8/Leu-2 as found in Group II.

The final and most differentiated group, group VI, represents SmIg-positive B-ALL (Table 4).

\section{T-Acute Lymphoblastic Leukemia}

T-acute lymphoblastic leukemic (T-ALL) represents $15 \%$ to $25 \%$ of cases of ALL. Clinical features associated with T-ALL include a high blast cell count, predominance of male patients, older patients (15-20 years), and mediastinal masses. T-ALL was originally identified by $\mathrm{E}$ rosette formation. The most sensitive marker for T-ALL is probably the CD7 pan-T 40 kilodalton $(\mathrm{kd})$ antigen. This antigen is present on most thymocytes and $\mathrm{T}$ cells but not on non-T-ALL or B cell lymphomas or leukemias. ${ }^{27-29}$ In a study of 23 patients with T-ALL, all cases expressed CD7. ${ }^{28}$ Interestingly, CD7 reacts with a small proportion of cases that appear to be myeloid leukemias. ${ }^{64}$ In addition, an unusually high incidence of CD10, Ia, and CD24 expression has been reported in adults with T-ALL. ${ }^{65}$ Recently, rearrangement of the T $\beta$ receptor gene in cases of T-ALL has been reported. ${ }^{46-50}$

Further subclassification of T-ALL is controversial. Reinherz and colleagues proposed a subclassification for T-ALL according to the level of thymic differentiation. ${ }^{59}$ Several elements of their subclassification of T-ALL have been confirmed; others are controversial. The most primitive thymocytes, referred to as early or stage I thymocytes, react with $\mathrm{T} 9$ and $\mathrm{T} 10$ antibodies and account for approximately $10 \%$ of the thymic cells. In their study, Reinherz and co-workers reported that most $\mathrm{T}-\mathrm{ALL}$ cells express antigens found on early thymocytes. The next level of thymic differentiation, which included the majority of thymocytes, is referred to as common or stage II. These cells lose $\mathrm{T} 9$, retain $\mathrm{T} 10$, and acquire CD1, CD4, and CD8 antigens. Approximately $20 \%$ of cases of T-ALL express this phenotype. Mature stage III thymocytes no longer express CD1 but segregate into CD4 or CD8 subsets similar to peripheral blood $T$ lymphocytes. Only rarely did Reinherz, et al find TALL cells with the phenotype of mature thymocytes or circulating $\mathrm{T}$ lymphocytes. In a more recent study, Roper and co-workers ${ }^{61}$ confirmed many of the findings reported by Reinherz, but reported some major differences. In this study, only one third of the T-ALL patients had the phenotype of early or stage I thymocytes; most had the phenotype of either intermediate or late stage thymocytes. In Table 5 we summarize these data and propose a scheme for the classification of T-ALL. The common marker for all of the subgroups is CD7. Nearly all cells also express CD5 and most express CD2 that identifies the Erosette receptor.

Although Roper and co-workers ${ }^{01}$ studied clinical correlations between these three groups of T-ALL, they found no unique clinical features among the subgroups and no differences in remission duration or survival. However, the groups were too small for statistically valid conclusions. Presently we believe it useful to subclassify T-ALL using this system so that data from a number of institutions can be analysed for clinical correlations between the subgroups of T-ALL.

\section{Non-Hodgkin's Lymphoma}

The non-Hodgkin's lymphomas are a diverse group of neoplasms whose pathologic classification are controversial. It is even more difficult to correlate pathologic classification with immunologic classification. There are, however, a number of immunologic patterns that emerge, and we will attempt to place them within the non-Hodgkin's lymphoma working classification ${ }^{66}$ as well as the Rappaport classification. ${ }^{67}$ 


\section{Follicular or Nodular Lymphomas}

The follicular or nodular lymphomas most likely represent neoplastic proliferation of lymph nodederived follicular center B lymphocytes. The cell type may be a small cleaved cell (nodular lymphocytic poorly differentiated lymphoma by the Rappaport classification), mixed small cleaved and cleaved or non-cleaved large cell (nodular mixed), or predominantly large cell (nodular histiocytic). The first two cell types fall within the working classification as lowgrade lymphoma, whereas the latter cell type as an intermediate grade lymphoma. While the predominantly small cleaved cell will almost always express high density monoclonal SmIg, larger cells may be SmIg negative. ${ }^{68,69}$ However, the small cleaved and large cells will routinely express Ia, CD19, and CD20 antigens and will often express the CD21 antigen. ${ }^{69}$ Interestingly, more than half of these cases will also express CD10, ${ }^{69},{ }^{70}$ Follicular lymphoma cells may be found in the patient's peripheral blood as a 'leukemic' phase of the disease (formerly referred to as lymphosarcoma cell leukemia). These cells can usually be differentiated from chronic lymphocytic leukemia (CLL) cells as they may express CD10, which is not expressed on CLL cells; they do not express the CD5 pan-T antigen found on CLL cells; and they generally will have a low percentage of mouse erythrocyte rosette formation (see below). ${ }^{71,72}$

\section{Malignant Lymphoma, Small Lymphocytic}

Malignant lymphoma, small lymphocytic (diffuse lymphocytic well-differentiated lymphoma in the Rappaport classification) is a low-grade malignancy and some cases may be identical to CLL. Also, included within this subclassification are the plasmacytoid lymphocytic subgroups with and without an IgM monoclonal gammopathy; some of these cases are similar to Waldenström's macroglobulinemia (described below). Surface markers on these small lymphocytic cells include low intensity SmIg, mouse erythrocyte receptors, $\mathrm{C}^{\prime} 3$ and receptors for the $\mathrm{Fc}$ portion of IgG and Ia, CD19, CD20, CD21, CD24, and other $B$ cell antigens. These features are similar to CLL and the cells also express the CD5 pan-T antigen.

\section{Malignant Lymphoma, Diffuse Small Cleaved Cell and Diffuse Mixed Small and Large Cell}

Malignant lymphoma, diffuse small cleaved cell (diffuse lymphocytic poorly differentiated lymphoma in the Rappaport classification) is an intermediate prognostic group. The cells are B lymphocytes that (similar to follicular lymphoma cells) usually display large amounts of monoclonal SmIg. Unlike follicular lymphoma cells, however, they do not usually express CD10. ${ }^{70}$ Similar to follicular lymphoma cells, they do not express the CD5 antigen as do cells from most small lymphocytic lymphomas and CLL. How- ever, all of these cell types have in common the expression of Ia, CD19, CD20, CD21, and other B cell antigens. ${ }^{69}$

The diffuse mixed small and large cell (diffuse mixed lymphocytic-histiocytic) lymphomas have not been extensively studied but are most likely predominantly B cell diseases. They are also considered an intermediate grade prognostic group.

\section{Malignant Lymphoma, Diffuse Large Cell and Large Cell Immunoblastic}

In the working classification, the diffuse large cell lymphomas are considered within the intermediate prognostic group, whereas large cell immunoblastic lymphoma is a high-grade malignancy. By the Rappaport classification, both of these cell types would be described as histiocytic. This is clearly a misdesignation since $80-90 \%$ of cases represent clonal expansions of malignant B cells. ${ }^{73} \mathrm{~A}$ high percentage of these cells express T9 and T10 antigens. ${ }^{68}$ Fifty-seven cases of diffuse large cell lymphoma were recently studied and divided into the following subgroups: (1) $\mathrm{CD} 20, \mathrm{CD} 19$, and SmIg positive; $\mathrm{CD} 21$ negative (50\%), (2) CD20, CD19, SmIg, and CD21 positive (30\%), (3) CD20 and CD19 positive; SmIg and CD21 negative (10\%), and (4) CD20 and SmIg positive, and CD21 negative $(10 \%){ }^{74}$ These data suggest that most of these lymphomas's represent the malignant counterpart of B cells at the mid-stage of differentiation. Ten to $20 \%$ of cases are T cell lineage; $2 \%$ are derived from the monocyte-myeloid lineage. Recently, clonal rearrangement of the $\mathrm{T} \beta$ receptor has been described in patients with $\mathrm{T}$-derived nonHodgkin's lymphoma. ${ }^{47,48}$

\section{Malignant Lymphoma, Lymphablastic}

Malignant lymphoma, lymphoblastic or lymphoblastic lymphoma is a high-grade malignancy. The nuclear membrane is characteristically deeply subdivided imparting either a lobulated (convoluted) appearance or a fine linear (nonconvulated) subdivision in a round nucleus. Lymphoblastic lymphoma represents approximately one-third of the cases of nonHodgkin's lymphomas in children and $5 \%$ of cases in adults. The disease is more prevalent in males; these patients often have a mediastinal mass. In some cases, the disease may evolve into a leukemic phase morphologically indistinguishable from T-ALL. The malignant cells are $T$ cells, form $E$ rosettes, react with $T$ cell antisera ${ }^{75-77}$ and have rearrangements of the $\mathrm{T} \beta$ receptor. ${ }^{78}$ Studies with monoclonal antibodies have demonstrated marked heterogeneity. Lymphoblastic lymphoma cells differ from T-ALL in that the cells rarely express the surface markers common to immature thymocytes (group I); ${ }^{79}$ phenotypes are equally divided among group II and group III T-ALL. Interestingly in $40 \%$ of cases, the cells are reported to express CD10; CD10 expression is less common in T-ALL $(10 \%){ }^{70}$ 


\section{Malignant Lymphoma, Small Noncleaved Cell}

This category includes Burkitt's lymphoma and other lymphomas previously designated undifferentiated non-Burkitt type (high grade). Burkitt cells from peripheral blood and bone marrow are usually classified as L3 by the French-American-British (FAB) criteria., ${ }^{80}$ Most cases of Burkitts lymphoma from Africa are associated with the Epstein-Barr virus (EBV); these are endemic. Most non-African cases (non-endemic) are EBV negative. ${ }^{81}$ Chromosomal abnormalities involving chromosome 8 (carrying the oncogene c-myc) and either 2,14 , or 22 occur in virtually all cases of endemic and non-endemic Burkitt's lymphoma. ${ }^{82}$ These are designated $\mathrm{t}(2 ; 8), \mathrm{t}(8 ; 14)$ and $t(8 ; 22)$, respectively. Usually the light chain class expressed on these cells is correlated with the translocation, i.e., $\kappa$ in $\mathrm{t}(2 ; 8)$ and $\lambda$ in $\mathrm{t}(8 ; 22)$. African Burkitt's lymphoma cells have $C^{\prime} 3$ and receptors for the Fc portion of IgG in addition to the EBV receptor. American Burkitt's lymphoma cells do not. ${ }^{81}$ Phenotyping of cell lines derived from patients with undifferentiated lymphoma of the Burkitt's and nonBurkitt's type have demonstrated heterogeneity. ${ }^{83}$ These studies suggest that Burkitt cells follow a divergent pathway of B cell evolution as they are all TdT negative (unlike early $B$ cell non-T ALL). The most primitive of the Burkitt cell lines are Ia and CD20 positive and may or may not express CALLA. Maturation was evident in other Burkitt cell lines by the expression of $C \mu$, surface membrane IgM, and/or IgM secretion. Some of these Burkitt cell lines also expressed the Tac antigen.

\section{Peripheral T Cell Lymphoma}

Peripheral T cell lymphoma would usually be classified as malignant lymphoma, large cell immunoblastic (high grade) under the working formulation. However, this tumour has unique features and will be described separately. The term 'peripheral $T$ cell lymphoma' is used to distinguish it from lymphoblastic lymphoma of presumed thymic origin. Peripheral $\mathrm{T}$ cell lymphomas are thought to derive from peripheral T lymphocytes in lymph nodes and other, nonlymphoid sites. These lymphomas comprise a broad spectrum of morphologic types of lymphocytes. In all instances the cells have $T$ cell markers admixed with epithelioid histiocytes, plasma cells, eosinophils, and vascular hypertrophy. Clinically, peripheral $\mathrm{T}$ cell lymphoma is characterized by generalized lymphadenopathy, weight loss, and a high incidence of pulmonary involvement. ${ }^{84}$ Surface markers are usually but not always characteristic of mature $T$ helper cells, ${ }^{85}$ including CD4 helper-associated antigen CD3, $C D 2$, and $C D 5$ pan-T antigens. Rearrangement of the $\mathrm{T} \beta$ receptor has been reported. ${ }^{78}$

\section{Ty Lymphoproliferative Disease}

$\mathrm{T} \gamma$ lymphocytes are a subset of $\mathrm{T}$ lymphocytes with receptors for the Fc portion of IgG. A high proportion of normal $\mathrm{T} \gamma$ lymphocytes are large granular lymphocytes. These cells are thought to be responsible for natural killer (NK) and antibody-dependent cellmediated cytotoxicity. A lymphoproliferative disorder made up of predominantly $\mathrm{T} \gamma$ lymphocytes has been described; we refer to this as chronic $\mathrm{T} \gamma$ lymphoproliferative disease. ${ }^{86}$ Typically, patients are elderly, males, with increased $T \gamma$ lymphocytes infiltrating the bone marrow and spleen. ${ }^{86,87}$ Although the disease is not rapidly progressive, neutropenia and recurrent infections are common. Most patients do not require chemotherapy. Variants of this disease, including a more aggressive form have also been described. ${ }^{88}$ Clonal chromosomal abnormalities, ${ }^{89}$ as well as clonal rearrangement of the $\mathrm{T} \beta$ receptor have been reported. ${ }^{57,90}$ Cells from chronic $\mathrm{T} \gamma$ lymphoproliferative disease usually contain acid phosphatase and $\beta$ glucuronidase and express the pan-T antigens $\mathrm{CD} 3, \mathrm{CD} 2$, the suppressor-associated antigens CD8, and the NK-associated antigens Leu-7 (HNK-1).

\section{Cutaneous T Cell Lymphoma (Mycosis Fungoides,} Sézary Cell Leukemia)

Skin lesions are the most prominent feature of patients with cutaneous $\mathrm{T}$ cell lymphoma. ${ }^{91}$ Lesions vary from limited plaques to diffuse plaques, tumours, and generalised erythroderma. Rare patients with limited plaque disease and less than $50 \%$ with generalised plaques and tumours have extracutaneous disease detected by light microscopy evaluation of peripheral blood and lymph nodes. Special studies including cytogenetic analysis and electron microscopy indicate blood involvement in over half of the patients with limited plaque disease and most patients with generalized plaques and skin tumours ${ }^{92}$ Analysis of the T $\beta$ receptor rearrangement will likely reveal a higher proportion of cases with blood involvement.

The malignant cells in this disorder are characterised by a cerebriform nucleus. In the skin, the cells are referred to as mycosis fungoides cells and in the peripheral blood as Sézary cells. Sézary and mycosis cells form $E$ rosettes, react with $T$ antisera and anti- $T$ monoclonal antibodies, ${ }^{93}$ and have clonal rearrangements of the $\mathrm{T} \beta$ receptors. ${ }^{54,55,85,94}$ In most cases, the cells express the phenotype associated with normal helper/inducer $\mathrm{T}$ lymphocytes (CD5, CD3, CD4) ${ }^{95}$ and function as helper $\mathrm{T}$ lymphocytes in in vitro assays. $^{96}$

\section{Adult T Cell Leukemia/Lymphoma}

Adult $\mathrm{T}$ cell leukemia/lymphoma is associated with a human retrovirus designated human $\mathrm{T}$ cell leukemia/ lymphoma virus-1 (HTLV-1). ${ }^{97}$ Virtually all patients tested have antibodies to HTLV-1.98 Patients with this disease have been identified primarily in Japan, the USA and the Caribbean. In the USA the patients are young (median age 33 years) predominantly black, 
and born in the Southeast. ${ }^{98}$ Common clinical features include a rapid onset of symptoms with rapidly progressive cutaneous lesions and hypercalcemia. Skin lesions are variable and include small and large discrete or confluent nodules, or nonspecific plaques, papules or patches. Patients have increased bony turnover with abnormal bone scans, elevated alkaline phosphatase and may have lytic bone lesions. ${ }^{99}$ Lymphocytosis is common, and circulating malignant cells are present in low numbers in most patients. Peripheral lymphadenopathy is common with retroperitoneal and hilar involvement in approximately $50 \%$ of cases. Bone marrow, gastrointestinal, pulmonary, leptomeningeal and hepatic involvement are somewhat less common $(20-50 \%)$. Response to combination chemotherapy is prompt and often complete, but duration of response is short (median 13 months). Opportunistic infections are extremely common in these patients.

The typical malignant circulating cells have moderately condensed nuclear chromatin, inconspicuous nucleoli, and a markedly irregular nuclear contour in which the nucleus is divided into several lobes. ${ }^{100}$ These cells typically express the phenotype of helper/ inducer T $\gamma$ lymphocytes, ${ }^{101}$ and CD25 that identifies the IL-2 receptor. ${ }^{102}$ Variability in the expression of CD2 and CD3 have been reported. ${ }^{101}$ Clonal rearrangements of the $\mathrm{T} \beta$ receptor are identified in cells from patients with adult $\mathrm{T}$ cell leukemia/lymphoma. ${ }^{48,50,78,82}$ The leukemic cells are reported to suppress B cells Ig secretion, ${ }^{103}$ by a complex mechanism involving induction of suppressor cells following activation of normal suppressor cell precursors. ${ }^{101}$

\section{Chronic Lymphocytic Leukemia and Prolympho- cytic Leukemia}

Chronic lymphocytic leukemia (CLL) is a monoclonal proliferation of SmIg-positive B lymphocytes. ${ }^{104,105}$ Clonality of CLL has been demonstrated by expression of a single Ig light chain, either $\kappa$ or $\lambda$, on the cell surface membrane. ${ }^{106}$ More sophisticated techniques have confirmed clonality by showing unique immunoglobulin idiotype specificities, ${ }^{107}$ a single pattern of glucose-6-phosphate dehydrogenase activity, ${ }^{108}$ clonal chromosome abnormalities, ${ }^{109}$ or immunoglobulin gene rearrangement. ${ }^{47}$ The malignant $B$ cell involved in CLL is an intermediately differentiated cell. The cell appears frozen in differentiation and does not mature to the final stage of B cell development, the mature plasma cell. However, recent data have demonstrated that in vitro treatment of these cells with phorbol esters or pokeweed mitogen can induce differentiation into mature immunoglobulinsecreting plasma cells. ${ }^{110}$ Under certain circumstances, CLL cells stimulated in vitro with phorbol esters differentiate into cells with cytoplasmic protrusions and other characteristics of hairy cell leukemia. ${ }^{111}$
The B lymphocyte characteristic of CLL displays a relatively small amount of $\mathrm{SmIg}$ and this has been used to distinguish CLL from the leukemic phase of nodular and diffuse lymphocytic lymphomas and from prolymphocytic leukemia where the cells generally display considerably more SmIg. ${ }^{12}$ Immunoglobulin isotype analyses indicates that most CLL display a single heavy chain class; typically, $\mu$ or $\mu$ and $\delta$. Less commonly, $\gamma, \alpha$, or no heavy chain determinant is found. CLL cells display either $\kappa$ or $\lambda$ light chains but never both. B-CLL cells display receptors for mouse erythrocytes, a feature characteristic of immature B lymphocytes. ${ }^{113}$ The cells also have the receptor for the $\mathrm{Fc}$ portion of $\mathrm{IgG}$ and complement with a relative increase of $C^{\prime} 3 \mathrm{~d}$ receptors (CR2) over $C^{\prime} 3 \mathrm{~b}$ receptors (CR1); this is typical of immature $B$ cells. ${ }^{114}$ B-CLL cells display several antigens, including Ia and human B cell antigens such as CD19, CD20, CD21 and CD24. One unanticipated finding was that B CLL cells display the CDS antigen previously thought to be restricted to T lymphocytes. CD5 on CLL cells was first recognised by using heteroantisera $^{15}$ and later with the T101 and equivalent monoclonal antibodies. ${ }^{32}$ The precise meaning of this anomalous expression of a $\mathrm{T}$ cell antigen is unclear; although a normal $B$ cell counterpart has been reported in human tonsil lymph nodes, ${ }^{116}$ and stimulation in vitro of normal B cells with phorbol ester may induce expression of this antigen. ${ }^{117}$ Recently, the TQ1 antigen, reported to define the inducer of suppression within the $T$ helper subset, was identified on 60 of 75 B-cell patients' cells. ${ }^{118}$

Rearrangement of immunoglobulin heavy and light chains have been reported as expected in B-CLL cells, however, rearrangement of the $\mathrm{T} \beta$ receptor has also been reported in approximately $10 \%$ of cases of B-CLL. ${ }^{50}$ This is analogous to the reported $\mathrm{T} \beta$ rearrangement in non-T (pre-B) ALL, and again emphasises that immunoglobulin and $\mathrm{T} \beta$ receptor rearrangement alone are not adequate to assign lineage.

In $3 \%$ to $10 \%$ of patients with CLL, the disease may evolve into a diffuse histiocytic lymphoma (Richter's syndrome). This may be associated with loss of the TQ1 antigen. ${ }^{18}$ Most data suggest that this evolution involves transformed follicular center B cells rather than histiocytes or macrophages. Some transformations represent evolution of the malignant clone with expression of the same monoclonal immunoglobulin and karyotypic abnormality present in the original CLL clone. ${ }^{19}$ In other cases, the lymphoma cells have different markers and immunoglobulin gene rearrangements than the original CLL cells; these cases probably represent the concomitant development of a B cell lymphoma or a histiocytic malignancy in patients with CLL. ${ }^{120.121}$

Prolymphocytic leukemia (PL) is related to CLL and is also likely to be derived from cells from the medullary cords of the lymph node. Immunoglobulin 
gene rearrangements of heavy and light chains have been reported. ${ }^{12}$ Patients with PL generally have extremely high blast counts and splenomegaly but lack significant lymphadenopathy. Prolymphoblasts are likely activated cells and appear morphologically immature with a fine lacy nuclear chromatin and one to two nucleoli; they may contain intracytoplasmic granules. These cells generally have higher density SmIg than CLL cells; they have Ia and CD19 antigens and may form rosettes with mouse erythrocytes. ${ }^{72} \mathrm{PL}$ cells from 14 consecutive patients reacted with the FMC7 monoclonal antibody that recognises an antigen found on one-half of normal B lymphocytes, while cells from only five of 20 patients with CLL reacted with this antibody. ${ }^{7}$

Approximately $5 \%$ of cases of CLL and PL result in a malignant proliferation of $\mathrm{T}$ rather than $\mathrm{B}$ cells. These cells react with $T$ antisera and anti- $T$ monoclonal antibodies reflecting the phenotypes of mature T lymphocytes; they lack SmIg and other B cell markers. ${ }^{123,124}$ Many of these patients have diffuse organ and skin involvement. ${ }^{123}$

\section{Hairy Cell Leukemia}

Hairy cell leukemia (leukemic reticuloendotheliosis) is characterised by invasion of the bone marrow and spleen by morphologically distinct mononuclear cells with 'hairy' cytoplasmic projections. ${ }^{125}$ These cells usually contain an isoenzyme of acid phosphatase (isoenzyme 5) that is resistant to tartrate; this isoenzyme is not unique to hairy cells. Surface markers of hairy cells are most consistent with a monoclonal proliferation of B lymphocytes. ${ }^{126} \mathrm{SmIg}$ with a single light chain is frequently identified, ${ }^{126}$ as are B cellassociated antigens. Interestingly, the PCA-1 antigen (but not the PC-1 antigen) typically on plasma cells, is identified on hairy cells; these data suggest that hairy cells may be pre-plasma cells. ${ }^{127}$ Perhaps the most convincing evidence for the B cell origin of hairy cells comes from studies of immunoglobulin genes which indicate clonal rearrangement of heavy chain genes and at least one light chain. ${ }^{128,129}$ Most cases of hairy cell leukemia demonstrate CD25 typically identified on select $\mathrm{T}$ cell malignancies and activated $\mathrm{T}$ cells. ${ }^{129}$

\section{Myeloma and Related Disorders}

The malignant B cells of Waldenström's macroglobulinemia, heavy chain disease, and multiple myeloma represent a further step in the maturation of medullary cord B cells. ${ }^{104}$ Like CLL cells, cells from patients with Waldenström's macroglobulinemia express SmIg and Ia, CD20, and CD19 antigens. ${ }^{11}$ Unlike CLL cells, however, these cells express the PCA-1 antigen and do not express the CD21 antigen nor rosette with mouse erythrocytes. ${ }^{72}$ The plasma cell and its malignant counterpart, the myeloma cell, represent the most differentiated $B$ lymphocytes.
These cells synthesise large quantities of immunoglobulin and have CIg, but usually lack SmIg and the Ia, CD20, CD21, and CD19 antigens. ${ }^{130}$ Plasma cells and myeloma cells, like other mature B lymphocytes, usually lack CD10, but a recent study has suggested that rare cases of CD10-positive myeloma represent an aggressive subtype with a poor prognosis. ${ }^{131}$ Interestingly, plasma cells and myeloma cells stain intensely with the OKT10 monoclonal antibody as well as the anti-PCA-1 and anti-PC-1 antibodies. ${ }^{132,133}$

\section{Conclusion}

The exciting advances in molecular biology and the hybridoma technology over the past 10 years have led to major advances in our understanding of the cellular origin of lymphoma and leukemia and will likely lead to a better understanding of the etiology of these diseases. Utilising these techniques it is now possible to more accurately diagnose and classify these disorders; these data may also have therapeutic implications. It is also possible to use molecular probes to detect minimal residual disease. In the future, monoclonal antibodies conjugated to isotopes, drugs, and/or toxins will likely have a role in the therapy of certain leukemias and lymphomas. We look forward to this exciting new era in cancer therapy and diagnosis.

\section{References}

1. Evans R I, Faldetta J J, Humphreys R E, Pratt D M, Yunis E J, Schlossman S F 1978 Peripheral human T cells sensitized in mixed leukocyte culture synthesize and express Ia-like antigens. Journal of Experimental Medicine 148: 1440

2. Fu S M, Chiorazzi N, Wang C Y, Montazeri G, Kunkel H, G, Ko H S, Gottlieb A B 1978 Ia-bearing T lymphocytes in man. Their identification and role in the generation of allogenic helper activity. Journal of Experimental Medicine 148: 1423

3. Winchester R J, Ross G D, Jarowski C J, Wang C Y, Halper J, Broxmeyer H E 1977 Expression of la-like antigens on human granulocytes during early phases of differentiation. Proceedings of the National Academy of Sciences USA 74: 4012

4. Ritz J, Pesando J M, Notis-McConarty J, Lazarus H, Schlossman SH 1980 A monoclonal antibody to human acute lymphoblastic leukemia antigen. Nature 282: 583

5. LeBien T W, Boúe D R, Bradley G, Kersey J 1982 Antibody affinity may influence antigenic modulation of the common acute lymphoblastic leukemia antigen in vitro. Journal of Immunology 129: 2287

6. Greaves M F, Hariri G, Newman R A, Sutherland D R, Ritter M A, Ritz J 1983 Selective expression of the common acute lymphoblastic leukemia (gp100) antigen on immature lymphoid cells and their malignant counterparts. Blood 61: 628

7. Nadler L M, Anderson K C, Marti G, Bates M, Park E, Daley J F, Schlossman S F 1983 B4, a human B lymphocyteassociated antigen expressed on normal mitogen-activated, and malignant B lymphocytes. Journal of Immunology 131 244

8. Stashenko P, Nadler L M, Hardy R, Schlossman S F 1980 Characterization of a human $B$ lymphocyte specific antigen. Journal of Immunology 125 : 1678

9. Nadler L M, Stashenko P, Hardy R, Van Agthoven A, Terhorst C, Schlossman S F 1981 Characterization of human B cell-specific antigen (B2) distinct from B1. Journal of Immunology 126: 1941

10. Nadler L M, Boyd A W. Park E, Anderson K C, Slaughenhoupt B, Thorley-Lawson D A, Schlossman S F 
1984 The B cell restricted glycoprotein (B2) is the receptor for Epstein-Barr virus (EBV). Blood 67: 78a (abstract)

11. Abramson C S, Kersey J H, LeBien T W 1981 A monoclonal antibody (BA-1) reactive with cells of human B lymphocyte lineage. Journal of Immunology 126: 83

12. Pirruccello S J, LeBien T W 1985 Monoclonal antibody BA-1 recognizes a novel human leukocyte cell surface sialoglycoprotein complex. Journal of Immunology 134: 3962

13. Brooks D A, Beckman I, Bradley J, NcNamara P J, Thomas M E, Zola H 1980 Human lymphocyte markers defined by antibodies derived from somatic cell hybrids. I. A hybridoma secreting antibody against a marker specific for human $B$ lymphocytes. Clinical and Experimental Immunology 39:477

14. Brooks D A, Beckman G R, Bradley J, McNamara P J, Thomas M, Zola $\mathbf{H} 1981$ Human lymphocyte markers defined by antibody derived from somatic cell hybrids. IV. A monoclonal antibody reacting specifically with a subpopulation of human B lymphocytes. Journal of Immunology 126: 1373

15. Anderson K C, Park E K, Bates M P, Leonard R C F, Hardy R, Schlossman S F, Nadler L M 1983 Antigens on human plasma cells identified by monoclonal antibodies. Journal of Immunology 130: 1132

16. Anderson K C, Bates M P, Slaughenhoupt B, Schlossman S F, Nadler L M 1984 A monoclonal antibody with reactivity restricted to normal and neoplastic plasma cells. Journal of Immunology 132: 3172

17. Foon K A, Todd R F III 1986 Immunologic classification of leukemia and lymphoma. Blood 69: 1-31

18. Nadler L M B cell/leukemia panel workshop: Summary and comments, in Reinherz E L, Haynes B F, Nadler L M, Bernstcin E D (eds): Leucocyte Typing, New York, Springer-Verlag 1986, p 3

19. Haynes B F Summary of T cell studies performed during the Second International Workshop and Conference on Human Leukocyte Differentiation Antigens, in Reinherz E L, Haynes B F, Nadler L M, Bernstein I D (eds): New York, Springer-Verlag, $1986 \mathrm{p} \mathrm{l}$

20. Reinherz E L, Schlossman S F 1981 The characterization and function of human immunoregulatory $\mathrm{T}$ lymphocyte subsets. Immunology Today 2: 69

21. Kung P C, Goldstein G, Reinherz E L, Schlossman S F 1979 Monoclonal antibodies defining distinctive human $T$ cell surface antigens. Science 206: 347

22. Reinherz E L, Schlossman S F 1980 Regulation of the immune response-inducer and suppressor T-lymphocyte subsets in human beings. New England Journal of Medicine 303: 370

23. Van Wauwe J, Goossens J, Decock W, Kung P, Goldstein G 1981 Suppression of human T-cell mitogensis and E-rosette formation by the monoclonal antibody OKT11A. Journal of Immunology 44: 865

24. Howard F D, Ledbetter J A, Wong J, Bieber C P, Stinson E B, Herzenberg L A 1981 A human T lymphocyte differentiation marker defined by monoclonal antibodies that block E-rosette formation. Journal of Immunology 126: 2117

25. Engleman E G, Warnke R, Fox R I, Diley J, Benike C J, Levy $R 1981$ Studies of a human $T$ lymphocyte antigen recognized by a monoclonal antibody. Proceedings of the National Academy Sciences USA 78: 1791

26. Royston I, Majda J A, Baird S M, Meserve B L, Griffiths J C 1980 Human $T$ cell antigen defined by monoclonal antibodies: The 65,000-dalton antigen of T cells (T65) is also found on chronic lymphocytic leukemia cells bearing surface immunoglobulin. Journal of Immunology 125: 725

27. Haynes B F, Mann D L, Hemler M E, Schroer J A, Shelhamer J H, Eisenbart G S, Strominger J L, Thomas C A Mostowski H S, Fauci A S 1980 Characterization of a monoclonal antibody that defines an immunoregulatory $\mathrm{T}$ cell subset for immunoglobulin synthesis in humans. Proceedings of the National Academy of Sciences USA 77: 2914

28. Link M, Warnke R, Finlay J, Amylon M, Miller R, Dilley J, Levy R 1983 A single monoclonal antibody identifies T-cell lineage of childhood lymphoid malignancies. Blood 2: 722

29. Vodinelich L Tax W, Bai Y, Pegram S, Capal P, Greaves M F 1983 A monoclonal antibody (WT1) for detecting leukemias of T-cell precursors (T-ALL). Blood 62: 1108

30. Uchiyama T, Broder S, Waldmann T A 1981 A monoclonal antibody (anti-Tac) reactive with activated and functionally mature human T cells. I, Production of anti-Tac monoclonal antibody and distribution of $\mathrm{Tac}(+)$ cells. Journal of Immunology 26: 1393

31. Reinherz E L, Morimoto C, Fitzgerald K A, Hussey R E, Daley J F, Schlossman S F 1982 Heterogeneity of human $\mathrm{T} 4+$ inducer $\mathrm{T}$ cells defined by a monoclonal antibody that delineates two functional subpopulations. Journal of Immunology 128: 463

32. Leder $P 1982$ The genetics of antibody diversity. Scientific American 246: 102

33. Croce C M, Shander M, Martinis T, Cicural L, D'Ancona G G, Dolby T W, Koprowski H 1979 Chromosomal location of the human immunoglobulin heavy chain genes. Proceedings of the National Academy of Sciences USA 76: 3416

34. Malcolm S, Barton P, Murphy C, Ferguson-Smith M A Bentley D L, Rabbitts T H 1982 Localization of human immunoglobulin $\kappa$ light chain variable region genes to the short arm of chromosome 2 by in situ hybridization. Proceedings of the National Academy of Sciences USA 79 4957

35. McBride O W, Hieter P A, Hollis G F, Swan D, Otey M C, Leder P 1982 Chromosomal location of human kappa and lambda immunoglobulin light chain constant region genes Journal of Experimental Medicine 155: 1480

36. Kirsch I R, Morton C C, Nakahara K, Leder P 1982 Human immunoglobulin heavy chain genes map to a region of translocations in malignant B lymphocytes. Science 216 301

37. Seidman J G, Leder $P 1978$ The arrangement and rearrangement of antibody genes. Nature 276: 790

38. Korsmeyer S J 1985 Hierarchy of immunoglobulin gene rearrangements in B-cell leukemias. pp 499-502. In: Waldmann T A, (moderator). Molecular genetic analyses of human lymphoid neoplasms: immunoglobulin genes and the c-myc oncogene. Annals of Internal Medicine 102: 497

39. Kitchingham G R, Rovigatti U, Mauer A M, Melvin S, Murphy S B, Stass S 1985 Rearrangement of immunoglobulin chain genes in $\mathrm{T}$ cell acute lymphoblastic leukemia. Blood 65 : 725

40. Acuto O, Reinherz, E L 1985 The human T-cell receptor structure and function. New England Journal of Medicine 312: 1100

41. Hedrick S M, Cohen D I, Nielsen E A, Davis M N 1984 Isolation of $\mathrm{cDNA}$ clones encoding $\mathrm{T}$ cell specific membrane associated proteins. Nature 308: 149

42. Hedrick S M, Nielsen E A, Kavalen J, Cohen D I, Davis M N 1984 Sequence relationships between putative $T$ cell receptor polypeptide and immunoglobulins. Nature 308: 153

43. Yanagi $Y$, Yoshikai $Y$, Leggett $K$, Clark S P, Aleksander I, Mak T W 1984 A human T cell-specific cDNA clone encodes a protein having extensive homology to immunoglobulin chains. Nature 308: 145

44. Isobe, M, Erikson J, Emanuel B S, Nowell P C, Croce C M 1985 Location of gene for $\beta$ subunit of human T-cell receptor at band $7 \mathrm{q} 35$, a region prone to rearrangement of T-cells. Science 228: 580

45. Jones C, Morse H G, Kao F-T, Carbone A, Palmer E 1985 Human $T$-cell receptor $\alpha$-chain genes: Location on chromosome 14. Science 228: 83

46. Minden M D, Toyonaga B, Ha K, Yanagi Y, Chin B, Gelfand E, Mak T 1985 Somatic rearrangement of T-cell antigen receptor gene in human $\mathrm{T}$-cell malignancies. Proceedings of the National Academy of Sciences USA 82 1224

47. O'Connor N T J, Wainscoat J S, Weatherall D J, Gatter K C, Feller A C, Isaccson P, Jones D, Lennert K, Pallensen G, Ramsey A, Stein H, Wright D H, Mason D Y 1985 Rearrangement of the T-ceil-receptor $\beta$ gene in the diagnosis of lymphoproliferative disorders. Lancet 1: 1295

48. Flug F, Pelicci P-G, Bonetti F, Knowles D M II, Dalla-Favera $R 1985 \mathrm{~T}$-cell receptor gene rearrangements as markers of lineage and clonality in $T$ cell neoplasms. Proceedings of the National Academy of Sciences USA 82 3460

49. Tawa A, Hozumi N, Minden M, Mak T W, Gelfand E W 1985 Rearrangement of the T-cell receptor $\beta$-chain gene in non-T-cell, non-B-cell acute lymphoblastic leukemia of childhood. New England Journal of Medicine 313: 1033

50. Waldmann T A, Davis M M, Bongiovanni K F, Korsmeyer S J 1985 Rearrangements of genes for the antigen receptor on 
T cells as markers of lineage and clonality in human lymphoid neoplasms. New England Journal of Medicine 313: 776

51. Sen L, Borella L 1975 Clinical importance of lymphoblasts with T markers in childhood acute leukemia. New England Journal of Medicine 292: 828

52. Brouet J C, Valensi F, Daniel M T, Flandrin G, Preud'homme J L, Seligmann M 1976 Immunological classification of acute lymphoblastic leukemias: Evaluation of its clinical significance in a hundred patients. British Journal of Haematology 33: 319

53. Flandrin G, Brouet J C, Daniel M T, Preud'homme J L 1975 Acute leukemia with Burkitt's tumor cells: A study of six cases with special reference to lymphocyte surface markers. Blood 45: 813

54. Chessels J M, Hardisty R M, Rapson N T, Greaves M F 1977 Acute lymphoblastic leukemia in children: Classification and prognosis. Lancet 2: 1307

55. Greaves M F, Brown G, Rapson N T, Lister T A 1975 Antisera to acute lymphoblastic leukemia cells. Clinical Immunology and Immunopathology 4: 67

56. Foon K A, Billing R J, Terasaki P, Cline M J 1980 Immunologic classification of acute lymphoblastic leukemia: Implications for normal lymphoid maturation. Blood 56: 1120

57. Vogler L B, Crist W M, Bockman D E, Pearl E R, Lawton A R, Cooper M D 1978 Pre-B cell leukemia. A new phenotype of childhood lymphoblastic leukemia. New England Journal of Medicine 298: 972

58. Crist W, Boyett J, Roper M, Pullen J, Metzgar R, Van Eys J, Ragab A, Starling K, Vietti T, Cooper M 1984 Pre-B cell leukemia respond poorly to treatment: A pediatric oncology group study. Blood 63: 707

59. Reinherz E L, Kung P C, Goldstein G, Levey R H, Schlossman S F 1980 Discrete stages of human intrathymic differentiation. Analysis of normal thymocytes and leukemic lymphoblasts of T-cell lineage. Proceedings of the National Academy of Sciences USA 77: 1588

60. Schroff R W, Foon K A, Billing R J, Fahey J L 1982 Immunologic classification of lymphocytic leukemia based on monoclonal antibody-defined cell surface antigens. Blood 59: 207

61. Roper M, Crist W M, Metzgar R, Ragab A H, Smith S Starling K, Pullen J, Leventhal B, Bartolucci A A, Cooper M D 1983 Monoclonal antibody characterization of surface antigens in childhood T-cell lymphoid malignancies. Blood 61: 830

62. Korsmeyer S J, Arnold A, Bakhshi A, Ravetch J V, Siebenlis U. Hieter P A, Sharrow S O, LeBien T W, Kersey J H, Poplack D G, Leder P, Waldmann T A 1983 Immunoglobulin gene rearrangement and cell surface antigen expression in acute lymphocytic leukemias of $\mathrm{T}$ cell and B cell precurso origins. Journal of Clinical Investigation 71: 301

63. Nadler L M, Korsmeyer S J, Anderson K C, Boyd A W, Slaughenhoupt B, Park E, Jensen J, Coral F, Mayer R J, Sallan S E, Ritz J, Schlossman S F 1984 B cell origin of non-T cell acute lymphoblastic leukemia. A model for discrete stages of neoplastic and normal pre-B cell differentiation. Journal of Clinical Investigation 74: 332

64. Chan L C, Pegram S M, Greaves M F 1985 Contribution of immunophenotype to the classification of differential diagnosis of acute leukemia. Lancet 1: 475

65. Sobol R E, Royston I, LeBien T W, Minowada J, Anderson K, Davey F R, Cuttner J, Schiffer C, Ellison R R, Bloomfield C D 1985 Adult acute lymphoblastic leukemia phenotypes defined by monoclonal antibodies. Blood 65: 730

66. The non-Hodgkin's lymphoma pathologic classification project, National Cancer Institute sponsored study of classification of non-Hodgkin's lymphomas. Summary and description of a working formulation for clinical usage. 1982 Cancer 49: 2112

67. Rappaport H, Winter W J, Hicks E B 1956 Follicular lymphoma. A re-evaluation of its position in the scheme of malignant lymphoma, based on a survey of 253 cases. Cance 9. 792

68. Aisenberg A C, Wilkes B M, Harris N L 1983 Monoclonal antibody studies in non-Hodgkin's lymphoma. Blood 61: 469

69. Anderson K C, Bates M P, Slaughenhoupt B L, Pinkus G S, Schlossman S F, Nadler L M 1984 Expression of human $B$ cell-associated antigens on leukemias and lymphomas: A model of human B cell differentiation. Blood 63: 1424
70. Ritz J, Nadler L M, Bhan A K, Notis-McConarty J, Pesando J, Schlossman S F 1981 Expression of common acute lymphoblastic leukemia antigen (CALLA) by lymphomas of B-cell and T-cell lineage. Blood 58: 648

71. Koziner B, Filippa D A, Mertelsmann R, Gupta S, Clarkson B, Good R A, Siegel F P 1977 Characterization of malignant lymphoma in leukemia phase by multiple differentiation markers on leukemic cells. Correlation with clinical features and conventional morphology. American Journal of Medicine 63: 556

72. Koziner B, Kempin S, Passe S, Gee T, Good R A, Clarkson B D 1980 Characterization of B-cell leukemias: A tentative immunomorphological scheme. Blood 56: 815

73. Horning S J, Doggert R S, Warnke R A, Dorfman R F, Cox R S, Levy R 1984 Clinical relevance of immunologic phenotype in diffuse large cell lymphoma. Blood 63: 1209

74. Freedman A S, Boyd A W, Anderson K C, Fisher D C, Pinkus G S, Schlossman S F, Nadler L M 1985 Immunologic heterogeneity of diffuse large cell lymphoma. Blood 65: 630

75. Nathwani B N, Kim H, Rappaport H 1976 Malignant lymphoma lymphoblastic. Cancer 38: 964

76. Roscn P J, Feinstein D I, Pattengale P K, Tindle B H, Williams A H, Cain M J, Bonorris J B, Parker J W, Lukes R J 1978 Convoluted lymphoma in adults, a clinicopathological entity. Annals of Internal Medicine 89: 319

77. Jaffe E S, Berard C W Lymphoblastic lymphoma: a term rekindled with a new precision. Annals of Intemal Medicine 89: 415

78. Bertness V, Kirsch I, Hollis G, Johnson B, Bunn P A Jr 1985 $T$-cell receptor gene rearrangements as clinical markers of human T-cell lymphomas. New England Journal of Medicine 313: 534

79. Bernard A, Boumsell L, Reinherz E L, Nadler L M, Ritz J, Coppin H, Richard Y, Valensi F, Dausset J, Flandrin G, Lemerle J, Schlossman S F 1981 Cell surface characterization of malignant $T$ cells from lymphoblastic lymphoma using monoclonal antibodies: Evidence for phenotype differences between malignant $T$ cells from patients with acute lymphoblastic leukemia and lymphoblastic lymphoma. Blood 57: 1105

80. Bennett J M, Catovsky D, Daniel M, Flandrin G, Galton D A G, Gralnick H R, Sultan C 1976 Proposals for the classification of the acute leukemias. British Journal of Haematology 33: 451

81. Magrath I 1981 Lymphocyte precursors and neoplastic counterparts in vivo and in vitro, pp 226. In, Berard C W (moderator): A multidisciplinary approach to non-Hodgkin's lymphomas. Annals of Internal Medicine 94: 218

82. Aisenberg A C 1984 New genetics of Burkitt's lymphoma and other non-Hodgkin's lymphomas. American Journal of Medicine 77: 1083

83. Benjamin D, Bazar L S, Jacobson R J 1985 Identification of stages of maturation arrest in Burkitt's lymphoma and induction of differentiation with teleocidin: implications for the origin of Burkitts lymphoma and a new classification. Blond 66: 185 (abstract)

84. Waldron J A, Leech J H, Glide A D, Flexner J M, Collins R D 1977 Malignant lymphoma of peripheral T-lymphocyte origin. Cancer 40: 1604

85. Green J P, York J C, Consar J B, Mitchell R T, Flexner J M, Collins R D, Stein R S 1984 Peripheral T-cell lymphoma: A clinicopathologic study of 42 cases. Journal of Clinical Oncology 2: 788

86. Reynolds C W, Foon K A $1984 \mathrm{~T} \gamma$-lymphoproliferative disease and related disorders in man and experimental animals: A review of the clinical, cellular and functional characteristics. Blood 64: 1146

87. Newland A C, Catovsky D, Linch D, Cawley J C, Beverly P, Sam Miguel J F, Gordon-Smith E C, Blecher T E, Shahriari S, Varadi S 1984 Chronic T cell lymphocytosis: A review of 21 cases. British Journal of Haematology 58: 433

88. Kadin M E, Kamoun N, Lamberg J 1981 Erythrophagocytic $\mathrm{T} \gamma$ lymphoma. A clinical pathologic entity resembling malignant histiocytosis. New England Journal of Medicine 304: 648

89. Laughran T P, Kadin M E, Starkebaum G, Abkowitz J L, Clark E A, Disteche C. Lum L G, Slichter S J 1985 Leukemia of large granular lymphocytes: association with clonal chromosomal abnormalities and autoimmune neutropenia, 
thrombocytopenia, and hemolytic anemia. Annals of Internal Medicine 102: 169

90. Aisenberg A C, Krontiris T G, Mak T W, Wilkes B M 1985 Rearrangement of the gene for the beta chain of the $T$-cell receptor in $\mathrm{T}$-cell chronic lymphocytic leukemia and related disorders. New England Journal of Medicine 313: 530

91. Schein P 1975 Clinical features, pp 542. In Lutzner $M$ (moderator): Cutaneous T-cell lymphomas, the Sézary syndrome, mycosis fungoides and related disorders. Annals of Internal Medicine 83: 534

92. Bunn P A, Huberman M S, Whang-Peng J, Schechter G P. Guccion J G, Matthews M J, Gazdar A F, Dunnick R, Fischmann B, Ihde D C, Cohen M H, Fossieck B, Minna J D 1980 Prospective staging evaluation of patients with cutaneous T-cell lymphoma: demonstration of a high frequency of extracutaneous dissemination. Annals of Internal Medicine 93: 223

93. Brouet J C, Flandrin G, Seligmann M 1973 Indications of the thymus-derived nature of the proliferating cells in six patients with Sézary's syndrome. New England Journal of Medicine 289: 341

94. Weiss L M, Hu E, Wood G S, Moulds C, Cleary M L, Warnke R, Sklar J 1985 Clonal rearrangements of T-cell receptor genes in mycosis fungoides and dermatopathic lymphadenopathy. New England Journal of Medicine 313: 539

95. Kung P C, Berger C L, Goldstein G, Lugerto P, Edelson R L 1981 Cutaneous T cell lymphoma: Characterization by monoclonal antibodies. Blood 57: 261

96. Broder S, Edelson R L, Lutzner M A, Nelson D L, MacDermott R P, Durm M E, Goldman C K, Meade B D, Waldmann T A 1976 The Sézary syndrome. A malignant proliferation of helper T cells. Journal of Clinical Investigation 58: 1297

97. Poiesz B J, Ruscetti F W, Gazdar A F, Bunn P A, Minna J D, Gallo R C 1980 Detection and isolation of type C retrovirus particles from fresh and cultured lymphocytes of a patient with cutaneous T cell lymphoma. Proceedings of the National Academy of Sciences USA 77; 7415

98. Bunn P A, Schechter G P, Jaffe E, Blayney D, Young R C, Matthews M J, Blattner W, Broder S, Robert-Guroff M, Gallo R C 1983 Clinical course of retrovirus-associated adult T-cell lymphoma in the United States. New England Journal of Medicine 309: 257

99. Bunn P A 1984 Clinical features, pp 543, in, Broder S (Moderator): T-cell lymphoproliferative syndrome associated with human T-cell leukemia/lymphoma virus. Annals of Internal Medicine 100: 543

100. Jaffe E 1984 Histopathology, pp 546, In Broder $S$ (moderator): $\mathrm{T}$-cell lymphoproliferative syndrome associated with human T-cell leukemia/lymphoma virus. Annals of Internal Medicine 100: 543

101. Morimoto C, Matsuyama T, Oshige C, Tanaka H, Hercend T, Reinherz E L, Schlossman S F 1985 Functional and phenotypic studies of Japanese adult $T$ cell leukemia cells. Journal of Clinical Investigation 75: 836

102. Tsudo M, Uchiyama T, Uchino H, Yodoi J 1983 Failure of regulation of Tac antigen-TCGF receptor in adult $T$-cell leukemia cells by the anti-Tac monoclonal antibody. Blood 5 : 1014

103. Uchiyama T, Sagawa K, Takatsuki K, Uchino H 1978 Effect of adult T-cell leukemia cells on pokeweed mitogen-induced normal B-cell differentiation. Clinical Immunology and Immunopathology 10: 24

104. Jaffe E S 1980 Non-Hodgkin's lymphomas as neoplasms of the immune system, pp 222, in Berard C W (moderator): A multidisciplinary approach to non-Hodgkin's lymphoma. Annals of Internal Medicine 94: 218

105. Gale R P, Foon K A 1985 Chronic lymphocytic leukemia: Recent advances in biology and treatment. Annals of Intcrnal Medicine 103: 101

106. Preud'homme J, Seligmann M 1972 Surface bound immunoglobulins as a cell marker in human lymphoproliferative diseases. Blood 40: 777

107. Giardina S L, Schroff R W, Woodhouse C S, Abrams P G, Rager H C, Kipps T J, Morgan A C. Foon K A 1985 The generation of monoclonal anti-idiotype antibodies to human B cell-derived leukemias and lymphomas. Journal of Immunology 135: 653
108. Fialkow P, Najfeld V, Reddy A, Singer J, Steinmann L 1978 Chronic lymphocytic leukemia: Origin in a committed B-lymphocyte progenitor. Lancet 2: 444

109. Han T, Ozer H, Bloom M, Sagawa K, Minowada J 1982 The presence of monoclonal cytoplasmic immunoglobulins in leukemic $B$ cells from patients with chronic lymphocytic leukemia. Blood 59: 435

110. Tötterman T H, Nilsson K, Sundström C 1980 Phorbol esterinduced differentiation of chronic lymphocytic leukemia cells. Nature 288: 176

111. Caligaris-Cappio F, Pizzolo G, Chilosi M, Bergui L, Semenzato G, Tesio L, Morittu L, Malavasi F, Gobbi M, Schwarting R, Campana D, Janossy G 1985 Phorbol ester induces abnormal chronic lymphocytic leukemia cells to express features of hairy cell leukemia. Blood 66: 1035

112. Aisenberg A, Wilkes B M 1981 Relevance of surface markers in chronic lymphocytic leukemia to acute lymphocytic leukemia. Cancer Research 41: 4810

113. Gupta S, Pahwa R, O'Reilly R, Good R A, Siegal F P 1976 Ontogeny of lymphocyte subpopulations in human fetal liver. Proceedings of the National Academy of Sciences USA 73: 919

114. Ross G D, Polky M J 1975 Specificity of human lymphocyte complement receptors. Journal of Experimental Medicine 141: 1163

115. Foon K A, Billing R J, Terasaki P I 1980 Dual B and $T$ markers in acute and chronic lymphocyte leukemia. Blood 55: 16

116. Caligaris C F, Gobbi M, Bojill M, Janossy G: Infrequent normal B lymphocytes express features of B-chronic lymphocytic leukemia. Journal of Experimental Medicine $155 ; 623$

117. Miller R A, Gralow J 1984 The induction of Leu-1 antigen expression in human malignant and normal $\mathbf{B}$ cells by phorbol myristic acetate (PMA). Journal of Immunology 133: 3408

118. Patrick C W, Libnoch J A, Milson T, Kortright K H, Keller R H 1984 Common variant of B cell chronic lymphocytic leukemia is defined by the monoclonal antibody TQ1. Blood 64 (abst): 195a

119. Brouet J C, Preud'homme J L, Seligmann M, Bernard J 1973 Blast cells with monoclonal surface immunoglobulin in two cases of acute blast crisis supervening on chronic lymphocytic leukemia. British Medical Journal 4: 23

120. Splinter T A W, Bom-van Noorloos A A, van Heerde P 1978 CLL and diffuse histiocytic lymphoma in one patient: Clonal proliferation of two different B cells. Scandinavian Journal of Haematology 20: 19

121. Van Dongen J M, Hoojkaas H, Michels J J, Grosueld G, de Klein A, van der Kwast T H, Prins M E F, Abels J Hageijer A 1984 Richter's syndrome with different immunoglobulin light chains and different heavy chain gene rearrangement. Blood 64: 571

122. Melo J V, Foroni L, Babapulle B, Lewis D S, Bennett M, Robinson D, Parreira L. Luzzatto L, Catovsky D 1985 Prolymphocytic leukemia of B cell type: Rearranged immunoglobulin (Ig) genes with defective Ig production. Blood 66: 391

123. Brouet J C, Flandrin G, Sasportes M, Preud'homme J L, Seligmann M 1975 Chronic lymphocytic leukemia of T-cell origin. Immunologic and clinical evaluation in eleven patients. Lancet 2: 890

124. Catovsky D, Okos A, Wiltshar F, Galetto J, Galton D A B Stathopoulos G 1973 Prolymphocytic leukemia of B and T cell type. Lancet $2: 232$

125. Bouroncle B A, Wiseman B K, Doan C A 1958 Leukemic reticuloendotheliosis. Blood 13: 609

126. Jansen J, LeBien T W, Kersey J H 1982 The phenotype of the neoplastic cells of hairy cell leukemia studies with monoclonal antibodies. Blood 59: 609

127. Anderson K C, Boyd A W, Fisher D C, Leslie D, Schlossman S F, Nadler L M 1985 Hairy cell leukemia: A tumor of pre-plasma cells. Blood 65: 620

128. Cleary M L, Wood G S, Warnke R, Chao J, Sklar J 1984 Immunoglobulin gene rearrangements in hairy cell leukemia. Blood 64: 99

129. Korsmeyer S J, Greene W C, Cossman J, Hsu S-M, Jensen J P, Neckers L M, Marshall S L, Bakhshi A, Depper J M, I ennard W I, Jaffe E S, Waldmann TA 1983 Rearrangement and expression of immunoglobulin genes and expression of 
Tac antigen in hairy cell leukemia. Proceedings of the National Academy of Sciences USA 80: 4522

130. Halper J, Fu S M, Wang C Y, Winchester R, Kunkel H G

1978 Patterns of expression of human 'Ia-like' antigens during the terminal stages of $B$ cell development. Journal of Immunology 120: 1480

131. Durie B G M, Grogan T M 1985 CALLA-positive myeloma: an aggressive subtype with poor survival. Blood 66: 229
132. Bhan A K, Nadler L M, Stashenko P, McCluskeyR T, Schlossman S F 1981 Stages of B cell differentiation in human lymphoid tissue. Journal of Experimental Medicine 154: 737

133. Foon F A, Schroff R W, Fligiel S 1982 Monoclonal antibody characterization of plasmacytoma cells associated with T lymphocytes with a suppressor phenotype. Clinical Immunology and Immunopathology 25: 59 